\title{
PEMIDANAAN TERHADAP PELAKU DENGAN GANGGUAN SEKSUAL
}

\author{
Yudi Gabriel Tololiu, Fakultas Hukum Universitas Udayana, e-mail: \\ yudigabriel73@gmail.com \\ Gde Made Swardhana, Fakultas Hukum Universitas Udayana, e-mail: \\ gmswar@yahoo.com
}

doi: https://doi.org/10.24843/KS.2020.v08.i10.p03

\begin{abstract}
ABSTRAK
Tujuan Studi ini untuk menganalisis mengenai pertanggungjawaban pidana serta pemidanaan yang ideal bagi orang dengan gangguan seksual saat melakukan tindak pidana. Penulisan artikel ini menggunakan metode penelitian hukum empiris, dengan jenis pendekatan yakni pendekatan kasus, perundang-undangan, analisis konsep hukum, serta juga perbandingan hukum. Hasil studi ini menunjukkan bahwa orang dengan gangguan seksual ketika melakukan tindak pidana sesungguhnya tidak mampu untuk dimintai pertanggungjawaban pidana. Hal tersebut didasarkan pada alasan bahwa jiwa atau diri orang tersebut sedang mengalami sakit atau cacat jiwanya. Pasal 44 ayat (1) KUHP sendiri menjelaskan bahwa seseorang tidak mungkin untuk dimintai pertanggungjawaban atau dipidana bila ternyata jiwanya sakit atau terganggu. Lebih lanjut seharusnya bagi mereka yang sedang mengalami sakit akan jiwanya terganggu saat melakukan tindak pidana, sejatinya tidak cocok untuk diberikan pidana penjara melainkan sanksi tindakan seperti rehabilitasi, perawatan, atau bahkan pengobatan. Sebagai bahan perbandingan di Jerman orang yang jiwanya terganggu atau tidak mampu untuk bertanggungjawab maka orang tersebut layak untuk dibawa ke rumah sakit bukan ke penjara.
\end{abstract}

\section{Kata Kunci: Pertanggungjawaban Pidana, Pemidanaan, Gangguan Seksual}

\begin{abstract}
The purpose of this study was to analyze criminal responsibility and ideal punishment for people with sexual disorders when committing a crime. The writing is done using empirical legal research methods, with the type of approach namely the case approach, the statute approach, analytical and conseptual approach, and also comparative approach. The results of this study indicate that people with sexual disorders when committing a crime are actually not able to be held responsible for the crime. This is based on the reason that the person's soul or self is experiencing mental illness or disability. Article 44 paragraph (1) of the Criminal Code itself explains that it is impossible for a person to be held accountable or sentenced if his soul is sick or disturbed. Furthermore, it should be that those who are experiencing mental illness have been disturbed when they commit a criminal act, in fact it is not suitable for imprisonment but for sanctions such as rehabilitation, treatment, or even medication. As a comparison, in Germany, a person whose soul is disturbed or unable to be responsible, then that person deserves to be taken to the hospital not to prison.
\end{abstract}

\section{Keywords: Criminal Responsibility, Punishment, Sexual Disorders}

\section{Pendahuluan}

1.1. Latar Belakang Masalah

Berkembangnya era atau zaman dan teknologi yang timbul dewasa ini, secara tidak langsung mendorong manusia untuk bisa mengikuti perkembangan tersebut. Perkembangan tersebut terjadi diseluruh sektor kehidupan manusia, baik ekonomi, 
teknologi, ilmu pengetahuan dan bahkan kesehatan. Dalam dunia kesehatan sendiri, tidak jarang timbul suatu penemuan-penemuan baru akibat dari terdapatnya suatu wabah, virus, atau penyakit baru. Timbulnya hal tersebut didorong oleh berbagai faktor, baik itu karena pola hidup manusia, permutasian dari penyakit lama, dan lain sebagainya. Perkembangan penyakit kejiwaan pun dengan berjalannya waktu menunjukan bahwa terjadi suatu penemuan-penemuan baru atau dalam arti terdapatnya suatu penyakit kejiwaan yang baru.

Munculnya suatu penyakit kejiwaan baru seharusnya tidak mendorong hukum untuk mengalami pembaharuan dalam konteks ini. Hal tersebut baru dianggap penting untuk bisa diadakan pembaharuan bilamana penyakit kejiwaan tersebut sesungguhnya bersinggungan langsung atau telah menimbulkan suatu reaksi masyarakat akibat dari penyakit kejiwaan tersebut. Dewasa ini tidak jarang diketemukan suatu kasus-kasus penyakit kejiwaan yang sesungguhnya dianggap sebagai tindakan yang tidak lazim hingga menimbulkan korban di masyarakat. Bahkan dari beberapa kasus tersebut sudah terdapat kasus yang mendapatkan Putusan Pengadilan.

Penyakit kejiwaan seksualitas yang akhir-akhir ini sering muncul ialah Eksibisionisme, Pedofilia, dan Fetish. Pedofilia pada dasarnya bersumber dari Bahasa yunani "paidofhilia" yang berasal dari 2 (dua) buah kata yakni "paido" yang artinya anak dan "fhilia" yang artinya cinta. Jadi secara harfiah pedofilia memiliki arti cinta anakanak. Namun dengan berkembangnya zaman istilah tersebut bergeser dan biasanya digunakan guna menjelaskan salah satu gangguan bertumbuhnya psikoseksual, yang dimana orang tersebut mempunyai keinginan yang tidak normal kepada anak kecil. ${ }^{1}$ Seorang yang mengidap Pedofilia mempunyai kecendrungan untuk melaksanakan kontak seksual kepada anak kecil, baik itu anak kecil laki-laki yang belum dewasa "pedofilia homoseksual" dan ataupun melakukan kontak seksual dengan anak kecil perempuan yang belum cukup umur, atau sering disebut dengan "pedofilia heteroseksual". ${ }^{2}$ Selain dari pada itu, Eksibisionisme sendiri berasal dari kata "exhibition" yang bermakna pameran, menunjukkan atau memperlihatkan alat vitalnya. Eksibisionisme merupakan kecendrungan dalam hal berimajinasi seksual yang bersifat harus serta berulang-ulang melalui cara mempertunjukkan sisi intimnya terhadap pihak lain. Eksibisionisme merupakan pemenuhan keingginan yang bersifat tinggi serta berkelanjutan guna meraih pemuasan hasrat seksual terhadap seseorang yang tidak saling mengenal serta orang tersebut tidak menghendaki hal tersebut, tidak jarang terhadap anak. Gangguan seksual ini melangsungkan masturbasi saat berimajinasi atau

1 Sadarjoen, Sawitri Supardi. Bunga Rampai Kasus Gugatan Psikoseksual (Bandung, PT. Refika Aditama, 2005), 71.

2 Alodia, Delvina, Jesslyn Lie, and Vini Anggreini. "Kejahatan Pedofilia Sebagai Perilaku Menyimpang Dan Upaya Penegakan Hukumnya." Jurnal Muara Ilmu Sosial, Humaniora, dan Seni 2, no. 2 (2019): 534-543. 
saat sungguh-sungguh mempertunjukkannya. ${ }^{3}$ Eksibisionisme merupakan salah satu penyakit yang tergolong dalam golongan paraphilia. ${ }^{4}$

Penyakit kejiwaan lainnya selain dari pada hal tersebut diatas, terdapat juga penyakit kejiwaan seksual yang akhir-akhir ini sedang hangat diperbincangkan, yakni Fetish. Fetish sendiri diartikan sebagai dorongan seksual yang diarahkan kepada benda milik lawan jenis kelamin, sebagai contoh seorang laki-laki yang terdorong hasrat seksualitasnya saat melihat pakaian dalam, sepatu, kaos kaki, atau bahkan rambut wanita. ${ }^{5} \mathrm{Hal}$ tersebut menunjukkan bahwa kecendurungan hasrat seksual orang dengan gangguan fetish lebih kepada benda atau barang mati. Dalam refrensi lainnya menjelaskan bahwa "Fetishism in general refers to the fixation on a non-living object (such as a particular type of gar-ment). According to the DSM (APA, 1994), the most common fetishes involve women's undergarments and shoes. A man with the paraphilia may masturbate while rubbing or sniffing the fetish object, or he may require that his partner wear the object or in some way interact with it during sexual activity." 6 Dalam terjemahan bebas maka dapat dimaknai bahwa Fetishisme pada umumnya mengacu pada fiksasi sebuah objek yang tidak hidup (seperti jenis pakaian tertentu). Menurut the DSM (APA, 1994), pakaian yang paling umum biasanya pakaian dalam wanita dan sepatu. Seorang pria dengan paraphilia (gangguan kelainan seksual), dapat bermasturbasi sambil menggosok atau mengendus objek fetish, atau ia mungkin mengharuskan pasangannya mengenakan objek atau dalam beberapa cara berinteraksi dengannya selama aktivitas seksual.

Beberapa kasus gangguan seksual seperti Eksibisionisme, Pedofilia, dan Fetish yang terjadi di Indonesia sendiri sesungguhnya telah menggambarkan bahwa terjadi pergeseran norma di tengah masyarakat. Gangguan seksual yang dialami beberapa orang telah meresahkan keamanan bahkan kenyaman dari masyarakat itu sendiri, dari beberapa kasus pelaku dengan gangguan seksual bahkan telah mendapatkan putusan pengadilan. Adapun beberapa kasus gangguan seksual yang telah mendapatkan putusan pengadilan ialah Putusan Pengadilan Negeri Nganjuk Nomor: 375/Pid.Susanak/2013/PN-NJK, atas nama terdakwa Eko Setiono Bin Bibit Suwanto yang dipidana penjara 3 (tiga) tahun dan denda Rp. 60.000.000,00 serta pengaturan bilamana pidana tersebut tidak dilakukan oleh terdakwa maka dirubah melalui pidana kurungan dengan waktu 6 (enam) bulan. Terdakwa dalam hal tersebut diyakinkan sah melangsungkan kekerasan seksual kepada anak, atau pengertian lainnya bahwa terdakwa mengidap penyakit kelainan seksual pedofilia.

3 Davinson, Gerald C, Neale, John M, dan Kring, Ann M. Psikologi Abnormal (Jakarta, Rajawali Pers, 2010), 624.

4 Anggreni, Made Sisca, Setiabudhi, I Ketut Rai, dan Purwani, Sagung Putri M.E. "Pertanggungjawaban Pidana Pelaku Tindak Pidana Eksibisionisme Dalam Hukum Pidana Indonesia" Kerta Wicara: Journal Ilmu Hukum 5, No. 01 (2016): 1

5 Wikipedia. Fetisisme. 2020. Retrieved from: https://id.wikipedia.org/wiki/Fetisisme Diakses pada tanggal 05 Agustus 2020)

6 Wiederman, Michael W. "Paraphilia and fetishism." The Family Journal 11, no. 3 (2003): 315-321. 
Putusan pengadilan dari perbuatan ganggungan seksual lainnya, yakni eksibisionisme yang mendapat putusan pengadilan ialah Putusan Pengadilan Negeri Denpasar No: 324/Pid.B/2014/PN.Dps, dengan nama terdakwa I Gusti Kadek Ariyasa dengan pidana penjara 6 (enam) bulan. Masih banyak lagi terdapat putusan-putusan pengadilan lainnya terhadap perbuatan yang sesungguhnya diakibatkan oleh prilaku gangguan seksual, baik itu pedofilia, eksibisionisme, dan kasus yang sedang hangat diperbincangkan ialah fetish.

Putusan pengadilan tersebut menggambarkan bahwa perbuatan-perbuatan dengan gangguan seksual dapat saja dipidana, dengan catatan bahwa perbuatan tersebut haruslah memenuhi setiap unsur-unsur tindak pidana dalam suatu pasal. Namun lebih lanjut bila diperhatikan bahwasannya perbuatan dalam konteks ini dilakukan oleh orang-orang yang sebenarnya tidak mampu untuk mempertanggungjawabkan perbuatannya. Perbuatan tersebut didorong oleh penyebab yang tidak wajar, yakni terdapat kelainan genetik yang sesungguhnya telah dibawanya sejak lahir. Penyakit bawaan inilah yang menyebabkan suatu kelainan diri sehingga perbuatannya pun dianggap tidak wajar oleh setiap orang. Secara yuridis, perbuatan tersebut dianggap tidak wajar dan merugikan masyarakat serta memenuhi unsur-unsur tindak pidana dalam suatu pasal, maka perbuatan tersebut dapat dipidana. Namun bila melihat lebih dalam lagi sesungguhnya terdapat alasan penghapus pidana yang dapat menghilangkan pidana tersebut. Perbuatan tersebut dilakukan bukan karena niat jahat melainkan kelainan atau penyakit yang terdapat dalam diri pelaku tersebut.

Pasal 44 KUHP pada pokoknya memberikan suatu penjelasan bahwa orang yang dirinya tidak normal dalam perkembangannya atau mengalami gangguan dikarenakan sakit, maka tidak dapat dipertanggungjawabkan tindakan pidana yang dilakukannya. Berdasarkan ketentuan tersebut sesungguhnya jelas bahwa orang dengan gangguan seksual bisa saja untuk tidak dapat dimintai pertanggungjawaban karena penyakit yang terdapat dalam dirinya. Namun karena telah terdapat hak orang lain yang dirugikan atau dengan kata lain telah terdapat orang yang dirugikan akibat dari perbuatan tersebut, maka sudah saatnya hukum menjawab permasalahan tersebut. Pidana penjara mungkin dapat memberikan rasa keadilan bagi pihak korban namun keadilan bagi terdakwa belumlah terakomodir, selepas terdakwa menyelesaikan masa hukuman di Lembaga Pemasyarakatan apakah penyakit secara otomatis akan hilang dalam dirinya, tentu tidak ada satu pun yang dapat menjamin hal ini. Oleh sebabnya perlu suatu pidana yang tepat untuk dapat memulihkan kembali orang yang terbukti melakukan tindak pidana akibat dari gangguan seksual.

Diperoleh beberapa penulisan atau riset mengenai perbuatan yang diakibatkan oleh gangguan seksual, antara lain : Sebuah riset yang dilakukan oleh Anak Agung Ayu Sinta Paramita Sari yang dilakukan pada tahun 2017 dengan judul “Pertanggungjawaban Pidana dan Pemidanaan Terhadap Pelaku Pedofilia Dalam 
Hukum Pidana Indonesia". ${ }^{7}$ Dalam riset tersebut disimpulkan bahwa Hukum Pidana Indonesia mengkualifikasikan Pedofilia sebagai suatu perbuatan atau perbuatan pidana cabul terhadap anak belum berumur dewasa. Dijumpai ketidakjelasan pengaturan dalam Pasal 44 KUHP terhadap putusan pengadilan yang berkaitan dengan hal ini, sehingga Hukum Pidana Indonesia seakan menganggap bahwa Pedofilia merupakan suatu Tindak Pidana bukanlah penyakit/ kelainan dalam diri sehingga layak untuk menerima pidana.

Berdasarkan hal tersebut belum terdapat penulisan atau penelitian yang membahas secara menyeluruh mengenai pertanggungjawaban dan pemidanaan yang ideal bagi pelaku yang mengidap gangguan seksual, mengingat begitu banyaknya penyakit gangguan seksual lainnya yang tidak mungkin satu per satu harus diatur dalam hukum positif Indonesia. Perlu pengaturan yang cocok untuk dapat mengakomodir semuanya itu.

\subsection{Rumusan Masalah}

Berkaitan dengan pemaparan hal tersebut diatas, dapat diangkat 2 (dua) masalah utama yang akan dibahas lebih lanjut, yakni :

1. Bagaimanakah pertanggungjawaban orang dengan gangguan seksual dalam Hukum Positif Indonesia?

2. Bagaimanakah pengaturan pemidanaan yang ideal terhadap orang dengan gangguan seksual di masa yang akan datang (ius constituendum)?

\subsection{Tujuan Penulisan}

Penulisan ini pada dasarnya bertujuan untuk menganalisis mengenai bagaimana sesungguhnya tanggungjawab secara pidana bagi seseorang yang melangsungkan perbuatan atau tindakan asusila namun orang yang bersangkutan memiliki kelainan seksual dan penulisan ini juga bertujuan untuk memberikan masukan bagaimana idealnya pidana terhadap orang dengan gangguan seksual.

\section{Metode Penelitian}

Adapun Metode Penulisan dalam penelitian yang dilakukan ialah jenis penulisan hukum empiris, dengan sifat penelitian deskriptif. Adapun macam-macam pendekatan yang dipakai dalam penulisan ini yakni Pendekatan Kasus (the case approach), Pendekatan Perundang-undangan (the statue approach), Pendekatan Analisis Konsep Hukum (analytical \& conceptual approach), dan pendekatan perbandingan (comparative approach). Sumber data yang digunakan dalam penulisan ini ialah berupa data sekunder yang bersumber dari penelitian kepustakaan.

7 Sari, Anak Agung Ayu Sinta Paramita. "Pertanggungjawaban Pidana Dan Pemidanaan Terhadap Pelaku Pedofilia Dalam Hukum Pidana Indonesia." Jurnal Magister Hukum Udayana (Udayana Master Law Journal) 6, No. 1 (2017): 23 


\section{Hasil dan Pembahasan}

\subsection{Pertanggungjawaban Orang dengan Gangguan Seksual dalam Hukum Positif Indonesia}

Pertanggungjawaban merupakan prinsip dasar di dalam hukum pidana. Pertanggungjawaban pidana sering diistilahkan dengan asas "geen straf zonder schuld" yang memiliki makna tidak ada penghukuman tanpa terdapat kesalahan. ${ }^{8}$ Suatu syarat yang dibutuhkan untuk terdapatnya pertanggungjawaban pidana ialah pelaku harus mampu mempertanggung jawabkannya, dengan perkataan lainnya wajib terdapat kemampuan bertanggungjawab dari pelaku itu sendiri. ${ }^{9}$ Menurut Van Hamel pertanggungjawaban merupakan suatu kondisi yang biasa serta kematangan psikis yang dimana mengemban 3 (tiga) jenis potensi guna : mengerti makna serta dampak tindakannya sendiri, mengerti kalau tindakannya tersebut tidak dilegalkan atau tidak diperbolehkan oleh masyarakat, serta menetapkan kemampuan terhadap tindakannya tersebut yang pada akhirnya bisa diartikan bahwa pertanggungjawaban bermakna kemampuan dan kecakapan. Pertanggungjawaban pidana belum lengkap bila dilakukan hanya tindakan pidananya saja, namun dipihak lain harus memiliki kesalahan, atau perbuatan batin yang bisa dipidana. ${ }^{10}$

Berdasarkan hal tersebut diatas, bila dilihat dalam Hukum Positif Indonesia sesungguhnya terdapat kejanggalan ketika orang dengan gangguan seksual atau orang yang mengidap penyakit seksual dipidana atau dihukum. Hukum positif Indonesia dalam beberapa peraturan perundang-undangan secara implisit mengatur beberapa perbuatan yang dilakukan oleh orang dengan gangguan seksual. Menunjuk kepada orang yang mengidap pedofilia, dalam KUHP perbuatan tersebut diistilahkan sebagai perbuatan cabul. Ketentuan yang mengatur mengenai perbuatan tersebut dapat dilihat dari ketentuan yang tertuang pada Pasal 290 ayat (2) KUHP yang pada pokoknya menyatakan "Seseorang yang berbuat cabul dengan seseorang yang diketahuinya belum berumur 15 tahun atau umurnya belum jelas, maka orang tersebut diancam pidana penjara paling lama 7 (tujuh tahun). " Sedangkan bagi seorang yang mengidap pedofilia dengan anak yang berjenis kelamin sama maka di pidana penjara paling maksimal 5 (lima) tahun selaras dengan ketentuan Pasal 292 KUHP.

Peraturan perundang-undangan diluar KUHP pun mengatur tentang perbuatan orang yang mengidap pedofilia. Undang-Undang Negara Republik Indonesia No. 35 Tahun 2014 Mengenai Perlindungan Anak memberikan pembedaan bahwa anak ialah mereka yang belum mencapai umur 18 tahun. Bagi mereka yang melakukan perbuatan

8 Saraswati, Ni Komang Ayu Gendis, dan Subawa, Made. "Pertanggungjawaban Pidana Pengguna Jasa Prostitusi Online Menurut Hukum Positid Di Indonesia" Kertha Wicara: Journal Ilmu Hukum 7, No.04 (2018): 35

9 Mahasena, Adhyaksa. "Pertanggungjawaban Pidana Bagi Pelaku Tindak Pidana Jual Beli Organ Tubuh Manusia." Jurnal Magister Hukum Udayana (Udayana Master Law Journal) 7, No. 1 (2018): 80.

10 Maulani, Diah Gustiniati. "Analisis Pertanggungjawaban Pidana dan Dasar Pemidanaan Terhadap Pelaku Tindak Pidana Penodaan Agama Di Indonesia." FIAT JUSTISIA: Jurnal Ilmu Hukum 7, no. 1 (2015). 
cabul terhadap anak seperti yang tuangkan pada Pasal 76D UU Perlindungan Anak, maka Pasal 81 mengatakan bahwa diberikan pidana penjara paling minimum (5) lima tahun serta paling maksimal 15 (lima belas) tahun serta denda paling maksimum Rp. 5.000.000.000,00 (lima miliar rupiah). UU Perlindungan anak juga memberikan pidana penjara dan denda seperti yang diatur dalam Pasal 82, bagi mereka yang melakukannya dengan kekerasan atau ancaman kekerasan, pemaksaan, berbuat tipu muslihat, melaksanakan serangkaian kebohongan, atau merayu anak seperti yang diatur dalam Pasal 76E. Hal ini menyatakan bahwa KUHP dan UU Perlindungan Anak memberikan pidana penjara dan denda bagi mereka yang melakukan perbuatan cabul atau dengan kata lain yang melakukan dengan keadaan gangguan seksual pedofilia.

Selain itu perbuatan gangguan seksual lainnya yang mendapatkan pidana dalam Hukum Positif Indonesia ialah Eksibisionisme. Adapun dasar hukum yang digunakan untuk memberikan pidana terhadap orang yang mengalami gangguan seksual dapat dilihat dari Putusan Pengadilan Negeri Denpasar No. 324/Pid.B/2014/PN.Dps dan Putusan Pengadilan Negeri Sleman No. 173/Pid.B/2016/PN.Smn. Kedua Putusan Pengadilan Negeri tersebut pada dasarnya menggunakan Pasal 281 ayat (2) KUHP untuk dapat memberikan pidana terhadap pelaku. Pasal 281 ayat (2) KUHP pada intinya menyatakan bahwa "Dipidana penjara maksimal 2 (dua) tahun delapan bulan atau denda maksimal Rp. 4.500,- seseorang yang dengan sengaja melanggar kesusilaan di hadapan pihak lain, yang muncul tidak dengan kehendaknya sendiri." Bila dilihat dalam peraturan perundang-undangan lainnya, Undang-undang Negara Republik Indonesia Nomor. 44 Tahun 2008 mengenai Pornografi Pasal 10 dan 36 secara implisit mengatur dan dapat memberikan pidana terhadap orang yang mengidap penyakit atau gangguan seksual Eksibisionisme.

Pasal 10 UU Pornografi pada dasarnya menyatakan bahwa pihak manapun dilarang untuk mempertunjukkan diri atau orang lain dimuka umum terkait hal ketelanjangan, eksploitasi seksual, persenggamaan, atau hal mengandung pornografi lainnya. Dalam Pasal 36 menjelaskan bahwa setiap orang yang melanggar ketentuan pasal 10 maka akan di pidana penjara maksimal 10 (sepuluh) tahun dan/atau pidana denda paling maksimal Rp. 5.000.000.000 (lima miliar rupiah). Berdasarkan Dasar Hukum yang digunakan dalam kedua Putusan Pengadilan tersebut dan juga ketentuan yang tertuang dalam Pasal 36 jo. Pasal 10 UU Pornografi maka setidaknya didapati gambaran bahwa berdasarkan ketentuan tersebut orang dengan gangguan seksual Eksibisionisme dapat dipidana atau dihukum. Meskipun tidak secara terang-terangan dimuat frasa "Eksibisionisme" dalam ketentuan tersebut, namun setidaknya yurisprudensi dan UU Pornografi meyakinkan kita bahwa sesungguhnya Hukum Positif Indonesia bisa mempidanakan orang yang melakukan perbuatan tersebut.

Terlepas dari hal tersebut, terdapat juga perbuatan gangguan seksual lainnya yang sedang hangat diperbincangan saat ini, yakni Fetish. Penyakit gangguan seksual Fetish yang diidap oleh Gilang saat ini dalam perkembangannya tidak dapat di jerat oleh ketentuan yang mengatur tentang tindak pidana asusila. Perbuatannya di jerat dengan Pasal 27 ayat (2) jo. Pasal 45 ayat (4) dan/atau Pasal 29 jo. Pasal 45B Undang- 
undang Negara Republik Indonesia No. 19 Tahun 2016 mengenai Informasi serta Transaksi Elektronik (ITE) dan/atau Pasal 335 KUHP tentang perbuatan tidak menyenangkan. Hal tersebut menunjukkan bahwasannya perbuatan Gilang sampai saat ini belum bisa diklasifikasikan sebagai tindak pidana asusila, atau dengan kata lain Fetish belum dapat dikategorikan tindak pidana asusila. Namun jika dilihat secara keseluruhan maka sesungguhnya terdapat hal prinsip yang perlu diperhatikan ketika ingin memberikan pidana kepada pelaku yang diduga berbuat suatu perbuatan pidana. Dalam hal memidana seseorang unsur kesalahan ialah unsur yang paling urgent yang harus ada. Kemampuan bertanggungjawab pada dasarnya suatu keadaan dimana pelaku dalam keadaan sehat atau normal, dimana ia bisa membedakan mana yang baik dan salah. Terdapat 2 (dua) faktor yang menentukan seseorang dikatakan mampu untuk bertanggungjawab, yakni akal dan kehendak. Faktor akal dapat diartikan sebagai keadaan dimana seseorang mampu untuk membedakan mana yang baik dan tidak, sedangkan faktor kehendak ialah keadaan dimana seseorang mampu membuat sinkron prilaku dengan pemikiran yang dapat memilih mana yang patut dan tidak.11

Kemampuan bertanggungjawab dalam KUHP didasarkan pada 2 (dua) aspek, yakni : kemampuan fisik dan kemampuan moral yang diatur dalam Pasal 44 KUHP. Pasal 44 KUHP ayat (1) pada dasarnya menyakatan yakni "seseorang yang melangsungkan tindakan yang tidak dapat dipertanggungkan terhadap dirinya oleh sebab dirinya sakit dalam perkembangannya atau tergganggu oleh sebab penyakit, tidaklah dihukum." Dalam hal ini jika dikaitkan dengan keadaan dimana seseorang melakukan suatu perbuatan yang dipengaruhi bukan dari niat yang jahat melainkan karena faktor jiwanya sakit, maka sesungguhnya berdasarkan ketentuan tersebut tidaklah dipidana. Pasal 44 KUHP memberikan pengertian bahwa sesungguhnya perbuatan yang dilakukan akibat bawaan penyakit tidak mungkin dapat dimintai suatu pertanggungjawaban. Pedofilia, Eksibisionisme, bahkan Fetish bukan merupakan golongan dari suatu tindak pidana, karena dalam ilmu kesehatan sendiri menyatakan bahwa hal tersebut merupakan penyakit yang telah dibawanya sejak lahir. Mereka yang mengidap ini tidak mungkin bisa membedakan layaknya orang normal, bahwa kebiasaan yang mereka lakukan sesungguhnya perbuatan yang tercela. Ketidakmampuan membedakan itulah yang sesungguhnya membuat diri pelaku terus melakukannya karena bagi mereka perbuatan itu dapat memenuhi hasrat kepuasan mereka.

Hal tersebut memberikan makna bahwa sesungguhnya berdasarkan ajaran mens rea suatu perbuatan yang dilakukan oleh seseorang yang sedang mengalami sakit atau jiwanya terganggu, atau yang dalam hal ini gangguan seksual maka sesungguhnya tidak mungkin untuk dapat dimintai pertanggungjawabannya, apalagi untuk dapat dipidana berdasarkan perbuatannya tersebut. Ajaran mens rea dengan tegas

11 Ariantri, Ni Wayan Diana, dan Wirasila, Anak Agung Ngurah. "Pertanggungjawaban Pidana Penyalahguna Narkotika yang dilakukan oleh Anak yang sudah Menikah" Kertha Wicara: Journal Ilmu Hukum 8, No. 10 (2019): 10-11 
mendasarkan prinsip bahwa suatu prilaku tiada membuat seseorang bersalah terkecuali pemikiran seseorang tersebut tidak baik..$^{12}$

\subsection{Pemidanaan yang Ideal terhadap Orang dengan Gangguan Seksual di Masa yang akan datang (Ius Constituendum)}

Pemidanaan pada dasarnya dapat diartikan sebagai penghukuman/ atau pemberian nestapa. Adapun yang dimaksud dengan penghukuman tersebut ialah berhubungan dengan pemberian hukuman serta alasan-alasan pembenar (justification) divonisnya hukuman tersebut kepada pelaku yang telah mendapatkan putusan pengadilan yang berkuatan hukum tetap (incracht van gewijsde) dinyatakan sah serta meyakinkan terbukti melakukan tindak pidana. ${ }^{13}$ Muladi berpendapat bahwa terdapat beberapa teori mengenai tujuan pemidanaan, yaitu : Teori Absolut, merupakan teori yang fokusnya ialah pada pemberian hukuman atau pidana yang ditimpakan kepada seseorang yang diasumsikan sudah melakukan perbuatan pidana, yang sepatutnya hal tersebut ialah suatu yang harus diterimanya sebagai suatu pembalasan akibat dari tindak pidana yang sudah dilakukan agar pemberian pidana tersebut mempunyai tujuan guna mencapai keadilan.

Adapun teori yang kedua ialah Teori Teleologis, teori ini menitikberatkan kepada pemberian hukuman dengan mempunyai suatu tujuan. Tujuan yang dimaksud ialah untuk mencegah setiap orang tidak melakukan suatu perbuatan pidana, dengan kata lain teori ini tidak bermaksud untuk memberikan pembalasan absolut atas keadilan. Teori Integratif atau teori paduan, teori ini merupakan gabungan yang menekankan bahwa pemberian sanksi harus mencerminkan keadilan retributive dengan catatan bahwa pemidanaan dipandang sebagai suatu kritik moral dalam menanggapi perbuatan yang diasumsikan menyimpang. ${ }^{14}$

Hukum Pidana Indonesia pada dasarnya memakai sistem dua jalur dalam pemidanaan (double track system), pelaku tindak pidana tidak hanya dikenakan suatu pidana melainkan juga bisa diberikan suatu tindakan atas dasar besar kecilnya suatu perbuatan pidana. Pengenaan hukuman yang berbentuk tindakan semestinya harus dicocokan dengan tujuan pemidanaan serta pedoman pemidanaan. Pemberian tindakan bukan atas dasar ancaman yang ada dalam perbuatan pidananya, melainkan didasarkan terhadap situasi serta kondisi dari orang yang berbuat. Dua pelaku yang dimaksud ialah pelaku yang tidak mampu bertanggungjawab dan pelaku yang mampu bertanggungjawab terhadap perbuatan yang dilakukannya. Hal tersebut seharusnya ada dalam konsep pemidanaan terhadap pelaku dengan gangguan seksual. Seperti yang dikemukakan dalam pembahasan sebelumnya bahwa sesungguhya perbuatan yang dilakukan oleh orang dengan gangguan seksual merupakan dorongan dari penyakit bawaan yang terdapat dalam dirinya. Perbuatan tersebut bukanlan perbuatan yang didorong seperti tindak pidana asusila pada umumnya, yang dilakukan memang murni

12 Sonbai, Alexander Imanuel Korassa. “Kebijakan Formulasi Pertanggungjawaban Pidana Pengguna Jasa Prostitusi Melalu Media Online" Acta Comitas: Jurnal Hukum Kenotariatan 4, No. 2 (2019): 278

13 Failin. "Sistem Pidana dan Pemidanaan Di Dalam Pembaharuan Hukum Pidana Indonesia." Jurnal Cendekia Hukum 3, No. 1 (2017) : 17

14 Darmadi, A.A. Ngurah Oka Yudistira. "Konsep Pembaharuan Pemidanaan Dalam Rancangan KUHP." Jurnal Magister Hukum Udayana (Udayana Master Law Journal) 2, No. 2 (2013): 6. 
dari niat jahat seseorang tersebut. Oleh sebabnya penjatuhan pidana penjara terhadap orang dengan gangguan seksual memberikan gambaran bahwa hal tersebut lebih kepada pemuasan rasa keadilan dari pihak korban.

Memang sangat disadari bahwa akibat dari perbuatan orang dengan gangguan seksual terhadap korban telah memberi dampak yang tidak baik bagi pihak korban. Pihak korban sangat memerlukan waktu yang panjang untuk memulihkan keadaannya, baik itu keadaan psikologi diri yang terganggu, traumatik akan kejadian tersebut, dan lain sebagainya. Sudah sewajarnya bila sudut pandang korban akan menuntut hukuman bahkan sanksi yang berat terhadap pelaku, namun hukum sejatinya haruslah memberikan suatu keadilan yang merata dalam hal ini. Pemberian pidana harus diberikan namun perlu disesuaikan dengan keadaan-keadaan yang berlaku. Keadaan orang dengan gangguan seksual seyogyanya mendapat tindakan rehabilitasi melihat kejiwaan yang sakit dari orang tersebut. Pidana penjara tidak akan memberikan pemulihan terhadap jiwa orang yang sakit, melainkan kepuasan dari rasa keadilan yang dituntut oleh pihak korban. Paradigma Hukum Pidana Indonesia seharusnya sudah mulai mengalami perubahan menanggapi ini.

Sanksi Pidana sejatinya memiliki sifat reaktif kepada suatu tindakan atau perbuatan, namun sanksi tindakan lebih bersifat antisipatif kepada orang yang melakukan tindakan tersebut. Bila perhatian sanksi pidana lebih kepada perbuatan salah seseorang lewat penjatuhan nestapa yang diharapkan menjadi jera, maka perhatian sanksi tindakan lebih kepada upaya memberikan bantuan guna seseorang yang melakukan suatu tindak pidana dapatlah berubah. ${ }^{15}$ Terlihat jelas bahwa hukuman pidana lebih memfokuskan diri terhadap unsur pembalasan. Sanksi pidana ialah sebuah nestapa yang sengaja ditimpakan terhadap seseorang yang melangsungkan tindak pidana. Sedangkan sanksi tindakan merupakan ide dasar dari perlindungan masyarakat serta pembinaan atau perawatan pelaku tindak pidana tersebut. Pemberian pidana penjara pada orang dengan gangguan seksual tidak dapat dijamin akankah bisa kembali menjadi orang yang tidak mengulangi perbuatannya tersebut. Orang dengan gangguan seksual seharusnya mendapatkan tindakan perawatan atau bahkan rehabilitasi agar dapat menjadi orang yang normal seperti pada umumnya.

Sebagai bahan perbandingan dalam Hukum Pidana Jerman mengatur bahwa orang yang dikelompokkan sebagai orang yang tidak mampu bertanggungjawab atau dengan kata lain tidak memiliki kemampuan bertanggungjawab maka tidak dapat dikenakan sanksi pidana penjara, melainkan sanksi tindakan rehabilitasi dengan membawanya ke Rumah Sakit. Hal tersebut bisa disimak dalam ketentuan yang tertuang dalam Pasal 63 German Criminal Code yang pada intinya menyatakan bahwa : "Article 63 of the Criminal Code provides that if someone commits an unlawful act without criminal responsibility pursuant to Article 20, the court orders their placement without maximum duration in a psychiatric hospital if a comprehensive evaluation of the defendant and his act reveals that as a result of his condition he can be expected to commit serious unlawful acts and that he therefore dangerous to the general public."

\section{Kesimpulan}

Adapun kesimpulan yang dapat diberikan yakni pertama, seseorang yang melakukan suatu perbuatan pidana namun dilatarbelakangi oleh gangguan seksual

15 Suwarsa, I Putu. "Pidana Pengawasan Terhadap Anak Yang Berhadapan Dengan Hukum Dalam Sistem Pemidanaan Di Indonesia." Jurnal Magister Hukum Udayana (Udayana Master Law Journal) 2, No. 3 (2013): 5 
sejatinya tidak bisa dipertanggungjawabkan. Meskipun dalam beberapa peraturan perundang-undangan secara tidak langsung mengatur perbuatan tersebut, namun yang perlu diingat bahwa perbuatan tersebut dilatarbelakangi oleh jiwanya yang sakit yang belum bisa membedakan mana yang baik dan buruk. Hal tersebut bisa disimak dalam ketentuan Pasal 44 ayat (1) KUHP yang pada intinya menyatakan bahwa orang yang jiwanya cacat atau terganggu tidaklah dapat dipidana. Kedua, bahwa penjatuhan sanksi pidana penjara dalam hal ini kuranglah tepat, karena sesungguhnya pidana penjara tersebut hanya memberikan kepuasan terhadap korban tapi tidak memberikan perbaikan terhadap pelaku. Rehabilitasi, perawatan, atau bahkan pengobatan merupakan alternative atau bahkan tambahan sanksi tindakan agar pelaku tidak mengulanginya kembali. Sebagai bahan perbandingan Pasal 63 German Criminal Code tidak memberikan sanksi pidana penjara terhadap orang yang tidak mampu untuk bertanggungjawab.

Adapun saran yang ingin diberikan dalam tulisan ini bahwa Hakim dalam menjatuhkan putusan seharusnya memperhatikan seluruh aspek secara kompherensif, peraturan perundang-undangan adalah satu kesatuan yang tidak dapat dipisahkan, mereka saling terkait dan melengkapi. Doktrin-doktrin dan asas-asas dalam Hukum pidana yang berlaku juga dapat dijadikan acuan dalam memberikan putusan. Selain itu, diharapkan kedepannya pengimplementasian sanksi tindakan berupa rehabilitasi, perawatan, atau bahkan pengobatan dapat diberikan bagi mereka yang menurut Pasal $44 \mathrm{KUHP}$ ayat (1) tidak dapat dipertanggungjawabkan karena jiwanya sakit atau cacat.

\section{DAFTAR PUSTAKA}

Buku

Davinson, Gerald C, Neale, John M, dan Kring, Ann M. Psikologi Abnormal (Jakarta, Rajawali Pers, 2010).

Sadarjoen, Sawitri Supardi. Bunga Rampai Kasus Gugatan Psikoseksual (Bandung, PT. Refika Aditama, 2005).

\section{Jurnal Hukum}

Alodia, Delvina, Lie, Jesslyn, dan Anggreini, Vini. “Kejahatan Pedofilia Sebagai Perilaku Menyimpang Dan Upaya Penegakan Hukumnya." Jurnal Muara Ilmu Sosial, Humaniora, dan Seni 2, No. 2 (2018).

Anggreni, Made Sisca, Setiabudhi, I Ketut Rai, dan Purwani, Sagung Putri M.E. "Pertanggungjawaban Pidana Pelaku Tindak Pidana Eksibisionisme Dalam Hukum Pidana Indonesia" Kerta Wicara: Journal Ilmu Hukum 5, No. 01 (2016).

Ariantri, Ni Wayan Diana, dan Wirasila, Anak Agung Ngurah. “Pertanggungjawaban Pidana Penyalahguna Narkotika yang dilakukan oleh Anak yang sudah Menikah" Kertha Wicara: Journal Ilmu Hukum 8, No. 10 (2019).

Darmadi, A.A. Ngurah Oka Yudistira. "Konsep Pembaharuan Pemidanaan Dalam Rancangan KUHP." Jurnal Magister Hukum Udayana (Udayana Master Law Journal) 2, No. 2 (2013).

Failin. "Sistem Pidana dan Pemidanaan Di Dalam Pembaharuan Hukum Pidana Indonesia." Jurnal Cendekia Hukum 3, No. 1 (2017).

Mahasena, Adhyaksa. "Pertanggungjawaban Pidana Bagi Pelaku Tindak Pidana Jual Beli Organ Tubuh Manusia." Jurnal Magister Hukum Udayana (Udayana Master Law Journal) 7, No. 1 (2018). 
Maulani, Diah Gustiniati. "Analisis Pertanggungjawaban Pidana dan Dasar Pemidanaan Terhadap Pelaku Tindak Pidana Penodaan Agama Di Indonesia." Fiat Justitia Jurnal Ilmu Hukum 7, No. 1 (2013).

Saraswati, Ni Komang Ayu Gendis, dan Subawa, Made. "Pertanggungjawaban Pidana Pengguna Jasa Prostitusi Online Menurut Hukum Positid Di Indonesia" Kertha Wicara: Journal Ilmu Hukum 7, No. 04 (2018).

Sari, Anak Agung Ayu Sinta Paramita. "Pertanggungjawaban Pidana Dan Pemidanaan Terhadap Pelaku Pedofilia Dalam Hukum Pidana Indonesia." Jurnal Magister Hukum Udayana (Udayana Master Law Journal) 6, No. 1 (2017).

Sonbai, Alexander Imanuel Korassa. "Kebijakan Formulasi Pertanggungjawaban Pidana Pengguna Jasa Prostitusi Melalu Media Online" Acta Comitas Jurnal Hukum Kenotariatan 4, No. 2 (2019).

Suwarsa, I Putu. "Pidana Pengawasan Terhadap Anak Yang Berhadapan Dengan Hukum Dalam Sistem Pemidanaan Di Indonesia." Jurnal Magister Hukum Udayana (Udayana Master Law Journal) 2, No. 3 (2013).

Wiederman, Michael W. "Paraphilia and Fetishism." The Family Journal : Counseling And Therapy For Couples And Families 11, No. 3 (2003).

\section{Internet}

Wikipedia. Fetisisme. 2020. Retrieved from: https://id.wikipedia.org/wiki/Fetisisme (Diakses pada tanggal 05 Agustus 2020) 